\section{B A Institute of \\ YK Business Administration \\ TK \\ Karachi \\ Leadership and Ideas for Tomorrow}

Business Review

Volume 16 Issue 1 January-June 2021

$8-17-2021$

\title{
Relationship between eWOM and purchase intention: Moderating role of culture (Evidence from University students of Pakistan)
}

Shaikh Obaidullah

University of Science \& Technology Bannu, Khyber Pakhtunkhwa

Asad Shahbaz

PIDE Islamabad

Tariq Majeed

PIDE Islamabad

Follow this and additional works at: https://ir.iba.edu.pk/businessreview

Part of the Advertising and Promotion Management Commons, Business Administration, Management, and Operations Commons, and the Marketing Commons

\section{(c) (1)}

This work is licensed under a Creative Commons Attribution 4.0 International License.

\section{Recommended Citation}

Obaidullah, S., Shahbaz, A., \& Majeed, T. (2021). Relationship between eWOM and purchase intention: Moderating role of culture (Evidence from University students of Pakistan). Business Review, 16(1), 101-120. Retrieved from https://doi.org/10.54784/1990-6587.1398

This article is brought to you by iRepository for open access under the Creative Commons Attribution 4.0 License and is available at https://ir.iba.edu.pk/businessreview/vol16/iss1/2. For more information, please contact irepository@iba.edu.pk. 


\title{
Relationship between eWOM and purchase intention: Moderating role of culture (Evidence from university students of Pakistan)
}

\author{
Shaikh Obaidullah • Asad Shahbaz • \\ Tariq Majeed
}

\begin{abstract}
This study is an attempt to find out the relationship between eWOM and Purchase Intention (PI) with the moderating role of culture among the varsities students in Khyber Pakhtunkhwa. For this purpose data was collected from business and management students of various public and private sector universities. The adopted version of constructs was used to obtain the data. The result indicates that the Consumer Review (CR), Brand Image (BI) and Source Credibility (SC) attributes of eWOM have a significant relationship with (PI), while Brand Equity (BE) shows an insignificant relationship with PI. Interestingly findings from a cultural perspective indicate no interactional effect. On the basis of results, it can be stated that (BE) is not part and parcel of eWOM but still it is an important characteristic of the online shopping process. Findings recommend that the current model may be used in other universities of various provinces across Pakistan.
\end{abstract}

Keywords eWOM · Purchase intention · Culture · Brand equity · Customer reviews . Source credibility

\section{Introduction}

WOM refers to face to face verbal conversation where individuals exchange their knowledge, information, and experience about product or services (Park et al 2007). Customers today do not respond actively to traditional techniques of advertisements therefore organizational priorities for promoting products and services is also changing. Firms are also changing their patterns regarding promo-

Shaikh Obaidullah

University of Science and Technology Bannu KP-Pakistan

E-mail: u.obaid@yahoo.com

Asad Shahbaz

Pakistan Institute of Development Economics-Pakistan

Tariq Majeed

Pakistan Institute of Development Economics-Pakistan

(c) Obaidullaj, S., Shahbaz, A. and Majeed, T. 2021 


\section{S. Obaidullah et. al}

tional activities and paying more emphasis on electronic word of mouth (eWOM) (Kilby 2007).

Word of mouth has an influential impact on customer purchase behavior (Daugherty and Hoffman 2014). Traditionally WOM was used to share different suggestions, points of view, and comments about the products and services. Now different platforms over the internet have changed its direction from typical (WOM) to electronic word of mouth which is termed as eWOM. This has started a new mode of electronic communication (Danniswara et al 2020). Currently, eWOM has become the most influential method in marketing studies and provides different forums for discussions e.g. consumer reviews on websites, blogs, and online shopping websites. More recently social media websites have made it easy for consumers to interact with each other and share their experiences about products and services without any limitations (Cheung and Thadani 2012). Consumers who plan to purchase a certain product now search for information on different blogs and websites before making a purchase decision (Pitta and Fowler 2005).

The relationship between eWOM and purchase intentions has been measured by many different variables. Recent studies showed that decision for making any purchase through eWOM depends upon the customer mindset and the content of consumer reviews (Knoll 2016). The credibility of the message source plays a vital role in shaping the belief of the customer. At the same time the marketing team must be very careful while selecting a convincing appeal for the desired message in their advertisements (Park et al 2007). The research study also revealed that brand equity is also of extra value and has a significant impact on customer attitude formation (Keller 2001).

There are also certain benefits and attributes which are always connected with a specific brand and help to create the image of the brand (Webster and Keller 2004). Furthermore, the image of the brand can also be developed by online consumer reviews because online internet surfing and writing recommendation also have a significant influence on potential customers (Park et al 2007). It is also very important for the strategy maker to keep customer feedback in terms of consumer reviews in their mind while making their promotional plans (Matute et al 2016).

This study investigates the role of culture as a moderator between eWOM and customer purchase intentions. Online shopping has become very popular over the last decade, having an enormous pool of potential customers. In eWOM customers not only purchase the online products, but they also search for different sources of information, potential user recommendations, and opinions which makes their purchase decision more effective (Hung and Li 2007).

Purchase intention of the customers is itself a part of consumer covert behavior which is expressed through different gestures made by the customer. Researchers have conducted their work across the world to investigate the relationship between eWOM and purchase intention of the customers, but the number of observed variables are different from one culture to another (Sharifpour et al 2016; Malik et al 2016). This study examines the impact of eWOM on customer purchase intentions. Different attributes e.g. brand image, consumer reviews, brand equity, and source credibility are used as variables to measure 
eWOM, and culture is also used as a moderating variable between eWOM and purchase intentions.

\section{Literature review}

Hennig-Thurau et al (2004) defined eWOM as any positive or negative statement made by potential actual or former consumers about a product or company which is available to a multitude of people and institutions via the internet. It is also worth mentioning that electronic word of mouth is quicker and fast-reacting as compared to traditional word of mouth. A previous research study showed that there is a significant impact of eWOM on customer purchase intentions (Gilly et al 1998). It is also proven by the study of Jalilvand and Samiei (2012) conducted in Iran, that eWOM plays a vital role and has a positive relationship with customer purchase intention. A similar study conducted by Fan and Miao (2012) in Taiwan found the same positive relationship between eWOM and customer purchase intention. During the last few decades, several communities have been formed that voluntarily exchange information regarding both new products and services. At the same time, the concept of virtual communities has arisen and these have emerged as the most powerful and rapid information sharing platforms throughout the globe. Those groups of people who have never interacted face to face with each other are also willing to exchange information about certain products and services by using social media (Turban et al 2015).

The findings of the research studies conducted in Pakistan and Malaysia on the relationship between eWOM and customer purchase intention show that eWOM has a significant and positive relationship with the purchase intention of the customer (Sharifpour et al 2016; Malik et al 2016). eWOM can be easily found in virtual communities through different societal norms and opinions posted by online communities. Mostly eWOM is available in terms of different online forums, blogs, and more specifically via online consumer experimental reviews (Kozinets et al 2010). Risk related to any product can also be minimized by creating positive eWOM because the positive feedback and remarks from the consumer, enable the potential customer to make their purchases more secure (Awad and Ragowsky 2008). Thus eWOM element is very important for customer purchase intention and this leads to the development of the following hypothesis. H1: eWOM has a positive and direct effect on purchase intention.

\subsection{The effect of source credibility on purchase intention}

Source credibility is defined as how much the message receiver has trust in the message sender. The relationship between source credibility and purchase intention of the customer is also investigated and the results showed that both variables are positively correlated with each other (Sharif et al 2016). It is customer belief and attitude towards the source of the message (Gunther 1992) that affects the message receivers level of belief, about what the source claims (West 1994). Sharif et al (2016) also studied the impact of message source credibility on the purchase intention of the customer and found a positive correlation 


\section{S. Obaidullah et. al}

between them.

Contemporary research studies in London checked the impact of the source credibility on customer purchase intentions whereby the results of the findings were also in line with the study conducted in Pakistan. The study finds out a positive relationship between source credibility and customer purchase intention (Erkan and Evans 2016).

Cheung et al (2009) further added that the anonymity of information source, accuracy, and source credibility has a low impact on the total information usefulness. Awad and Ragowsky (2008) stated in their studies that the credibility of the message source is a primary factor in the customer decision-making process and also reduces the uncertainty level in both business and social interaction. Thus the following is predicted: H1a: Source credibility has a positive and direct effect on purchase intention.

\subsection{The effect of brand equity on purchase intention}

Aaker (1991) defined brand equity as 'a set of assets and liabilities linked to a brand, its name, and symbol that adds to or subtracts from the value provided by its product or service to a firm and/or to that firm's customers'. According to the study by Chen and Chang (2008) that investigated the relationship between brand equity and customer purchase intention a positive relationship exists between these two variables. While in 2013 another study conducted in Spain also demonstrated the same positive relationship between the said two variables (Buil et al 2013). Mostly brand equity of the products is created through the increased number of shares in the market and high margins of profits (Yasin et al 2007).

A research study conducted in Gujrat (Pakistan) by (Ahmed and Zahid 2014) proved that brand equity plays a vital role in developing relationships with customer purchase intention. According to Keller (2001), brand equity can be best measured via three major categories i.e. customer mindset, product market, and financial market. The mindset of the customer shows the level of awareness, attachment, and loyalty that a customer has towards the brand. The logic of the product market reflects the performance of the brand in the market place, while the financial market considers the brand value as a strong financial asset.

Recent studies conducted in Pakistan have confirmed that the relationship between brand equity and customer purchase intention has a positive relation with purchase intention (Sharifpour et al 2016; Calvo-Porral and Lévy-Mangin 2014). According to Babac (2011), brand equity can be highly influenced by the content trending on social media in three ways. First, social media provides an easy and direct way for both customers and businesses to interact with each other. Secondly with the help of social media, awareness, of the brand increases which directly affects the customer's daily life. Third, it also increases the involvement process of customers by indirectly promoting the brand through electronic word of mouth.

It is proven by the studies of Calvo-Porral and Lévy-Mangin (2014); Mayer 
(2003) that brand equity paves way for customer purchase intentions. Brand equity is the main power of the brand which is derived through the attractiveness and familiarity which a brand has earned with the passage of time. This leads to the development of the following hypothesis. H1b: Brand equity has a positive and direct effect on purchase intention.

\subsection{The effect of consumer reviews on purchase intention}

Several scholars have studied the relationship between electronic word of mouth and customer purchase decisions (Fan and Miao 2012; Sharifpour et al 2016; Malik et al 2016). Unknowingly customer's online reviews about any product or services influence their attitude, behavior, and companies' sales as well as profitability both positively and negatively (Burton and Khammash 2010). The research work of (Al Mana and Mirza 2013) which was conducted in Saudi Arabia indicates that the relationship between consumer reviews and purchase intention is highly significant.

Park et al (2007) reported that online trade enables consumers to give direct feedback and share their knowledge and experiences about the products for the sake of influencing potential customers. In 2015 another study was conducted by a Chinese researcher which also investigated the same variables and their results were in line with the study conducted in Saudi Arabia. Another study conducted in Europe also confirms the findings of Park et al (2007); Mo et al (2015) and indicated that customer reviews is one of the major parts of eWOM that shape customer purchase intention. Another latest study about eWOM and purchase intention conducted in Netherlands whose findings were in line with the earlier studies conducted in China and Saudi Arabia also supported the positive relationship between consumer reviews and customer purchase intention (Constantinides and Holleschovsky 2016).

A survey was conducted where the collected information reveals that online customer reviews play a major role in shaping customer purchasing decisions. Around two-thirds of respondents reported that before purchasing any product they must consult blogs, online reviews, and other sources of information. Moreover, customers were of the opinion that word of mouth is still a major factor which influences customer buying behavior (Harris and Rae 2009). The studies of Chang and Chin (2010) revealed that customer feedback and online reviews positively influence the purchase decisions of the customer. Thus the following hypothesis is postulated: H1c: Consumer reviews have a positive and direct effect on purchase intention.

\subsection{The effect of brand image on purchase intention}

The perception and association of a product in the mind of the customer is the real brand image. All these associations have different dimensions because it generates their different responses in term of purchase and word of mouth (Keller 2001). According to Webster and Keller (2004) brand image contains different sort of benefits and attributes which are also interlinked with the specific brand 


\section{S. Obaidullah et. al}

and makes the brand more unique as compared to the other brands. Expectations play an integral role in developing the brand image, therefore meeting the expectations of the customer is also important for marketers to create a healthy brand image. For this purpose maintaining the quality of the product is also among the top priorities of the marketing department of the companies.

It is proved by the research study of Jalilvand and Samiei (2012) which was conducted in Iran that the image of the brand plays a critical role and develops a positive relationship with customer purchase intention. A study was conducted in Austria and UK which also investigated the relationship between brand image and customer purchase intention and revealed that brand image has a positive impact on customer purchase intention (Diamantopoulos et al 2011).

A study by Malik et al (2013) was conducted in Pakistan where the same variables were tested and results have shown a positive relationship between brand image and customer purchase intention. Another study was conducted in Thailand which also investigated the same relationship where the brand image was taken as an independent variable. The findings of the study declared a positive relationship between the brand image and customer purchase intention (Wang and Tsai 2014). Therefore the image of the brand is a vital component for customer purchase intention, leading to the following hypothesis. H1d: Brand image has a positive and direct effect on purchase intention.

\subsection{The effect of culture as a moderator}

There is no cultural uniformity across the globe because culture is dynamic in nature, which constantly changes with the passage of time (Hatch and Farber 2004). According to Hofstede (1997) culture is the blend of acquired behaviors of groups based on their own norms and tradition, which are then transmitted from one generation to another. The process of decision-making also depends on the basic norms and values of the culture because our psychological process considers these factors before making any decision in our daily lives (Triandis 2008). Research on the moderating role of culture between eWOM and purchase intention is very rare. Dang and Nandakumar (2017) investigated the relationship between eWOM and purchase intention which indicates that culture has a strong impact on eWOM and purchase intention.

Tang (2017) investigated the moderating role of culture between eWOM and performance of the product. Results show the positive role of cultural attributes on the variables under study. Another study conducted by Schumann et al (2010), tried to find out the moderating role of culture between eWom and service quality perception. Findings indicate that culture did not moderate the relationship between eWOM and service quality. Based on literature the following hypothesis is developed. H2: Culture moderates the relationship between eWOM and purchase intention. 


\section{Theoretical framework}

Figure 1 below displays the theoretical model for this study and the integration of the proposed hypotheses.

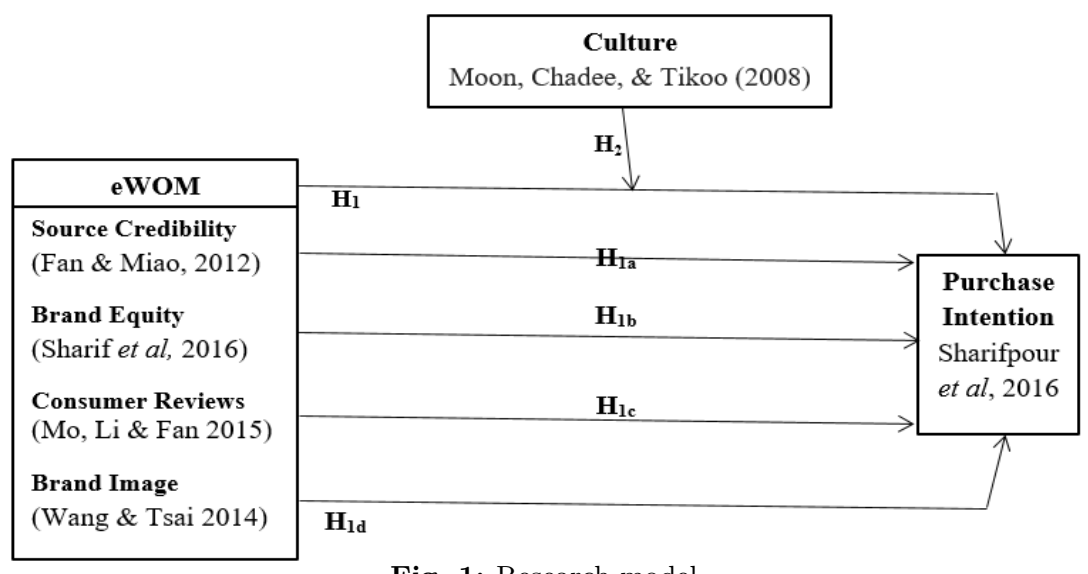

Fig. 1: Research model

\subsection{Research Hypotheses}

H1: eWOM has a positive and direct effect on purchase intention.

H1a: Source credibility has a positive and direct effect on purchase intention.

H1b: Brand equity has a positive and direct effect on purchase intention.

H1c: Consumer reviews have a positive and direct effect on purchase intention.

H1d: Brand image has a positive and direct effect on purchase intention.

$\mathrm{H} 2$ : Culture moderates the relationship between eWOM and purchase intention.

\section{Research methodology}

\subsection{Research design}

A cross-sectional research design was used in this study and data was collected from the participants by distributing questionnaires among them using the quantitative survey method. The current study is based on investigating the relationship between different variables under study, hence it is causal in nature as the effect of one variable was investigated with the outcome. The unit of analysis consists of individuals (students of selected discipline) from the selected universities and it was purely based upon the responses from them.

Business Review: (2021) 16(1):101-120 


\section{S. Obaidullah et. al}

\subsection{Population and sample}

The target population in the current study are the students of management sciences of different public sector universities in Khyber Pakhtunkhwa, including the University of Science and Technology Bannu, Gomal University D.I. Khan, and the University of Peshawar. Purposive sampling technique which is a non-probability sampling technique was used in this study. The sample size $(\mathrm{n}=320)$ was calculated using the formula, $\mathrm{n}=\mathrm{N} / 1+\mathrm{N}(\mathrm{e} 2)$ (Yamane 1967) where $N$ denotes the population and $e=0.05$ indicates the level of significance.

\subsection{Instruments}

In order to measure the response related to the variable under study a questionnaire adapted from the previous research studies was used. All the relevant instruments are discussed in detail below.

\subsection{1 eWOM}

Generally, there are several pieces of evidence that eWOM can be measured by using a different number of attributes such as source credibility by Ohanian (1990), brand equity, and brand image by Davis et al (2009) and customer reviews by Bambauer-Sachse and Mangold (2011). In this study, eWOM is measured by Source credibility, Brand image, Brand equity, and Customer reviews. The response of respondents are measured on a five-point Likert scale where 1 is used to indicate Strongly agree, 2 Agree, 3 Neutral, 4 Disagree and, 5 Strongly disagree.

\subsubsection{Culture}

Culture is an important factor that affects the relationship between eWOM and purchase intention as found by Rhyne et al (2002). Rhyne et al (2002) measure the construct 'culture' by means of eleven indicators using a formative measurement model. The same indicators were floated to the target audience in terms of the questionnaire and their response was recorded by using a scale from 1 to 5 (strongly agree to strongly disagree).

\subsubsection{Purchase intention}

The purchase intention of customers is used as a dependent variable in the current study. This construct is measured on the basis of five indicators each on a scale from 1 to 5 (SA to SDA).

\subsection{Path diagram}

Figure 2 displays the path diagram of the study. 


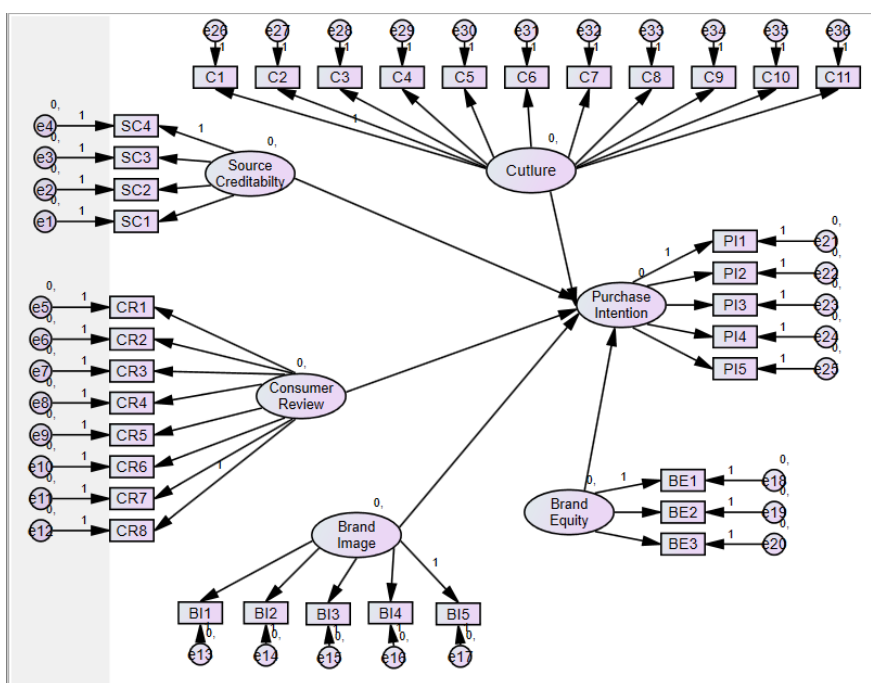

Fig. 2: Path diagram

\subsection{Analysis of data}

We used the structural equation modeling technique, which is the most prominent technique for latent variables analysis, to analyze correlation, regression, and moderation effects. The reliability of the constructs was checked with the help of Cronbach alpha as well as Convergent and discriminant Confirmatory factor Analysis (CFA) via AMOS. In the next phase, Pearson correlation analysis was conducted to check the relationship between all the selected variables. In the third step multiple regression analysis is used to determine the relationship between eWOM attributes and purchase intention on the basis of model fit, $\mathrm{R}$, and $R^{2}$ statistics. Finally, moderation analysis was performed through Preacher and Hayes (2008) macros with bootstrapping statistical technique.

\section{Results and discussion}

Table 1 describes the summary statistics of dependent, independent, and moderating variables. The mean value of all the variables is higher than their standard deviation which is considered a good sign for further analysis. The result of all the variables are shown in table 1 .

The normal ranges of skewness and kurtosis for a variable to be considered as distributed normally are (-1, to 1$)$ or $(-1.96$ to 1.96$)$ and (-2 to 2$)$ respectively. As the values of skewness and kurtosis for all variables are under the assumption of normality range, hence it is concluded that this data is normally distributed. 
S. Obaidullah et. al

Table 1: Descriptive statistics

\begin{tabular}{lccccccc}
\hline & eWOM & $\begin{array}{l}\text { Consumer } \\
\text { Reviews }\end{array}$ & $\begin{array}{l}\text { Source } \\
\text { Credibility }\end{array}$ & $\begin{array}{l}\text { Brand } \\
\text { Eq- } \\
\text { uity }\end{array}$ & $\begin{array}{l}\text { Purchase } \\
\text { Intention }\end{array}$ & $\begin{array}{c}\text { Brand } \\
\text { Image }\end{array}$ & Culture \\
\hline $\mathrm{N}$ & 320 & 320 & 320 & 320 & 320 & 320 & 320 \\
Mean & 2.319 & 2.392 & 2.364 & 2.473 & 2.443 & 2.363 & 2.275 \\
Median & 2.305 & 2.375 & 2.250 & 2.400 & 2.400 & 2.200 & 2.182 \\
Std. Dev & 0.478 & 0.722 & 0.721 & 0.806 & 0.823 & 0.714 & 0.562 \\
Skewness & -0.083 & 0.525 & 0.187 & 0.291 & 0.333 & 0.270 & 0.469 \\
Std. Error & 0.136 & 0.136 & 0.136 & 0.136 & 0.136 & 0.136 & 0.136 \\
Kurtosis & 0.241 & 0.809 & 0.032 & 0.017 & -0.163 & -0.172 & 0.732 \\
Std. Error & 0.272 & 0.272 & 0.272 & 0.272 & 0.272 & 0.272 & 0.272 \\
Min & 1.000 & 1.000 & 1.000 & 1.000 & 1.000 & 1.000 & 1.000 \\
Max & 3.890 & 5.000 & 4.500 & 5.000 & 5.000 & 4.400 & 4.640 \\
\hline
\end{tabular}

\subsection{Demographics}

The majority of the respondents were males $61.25 \%$ and females made up only $38.75 \%$ of this study. The major portion of the responses came from the respondents aged between 18-21 (38.125\%) and 22-25 (51.562\%) which becomes $89 \%$ of the total sample study. Rest of the respondents were between the age of $26-30,6.562 \%$, between $31-40,3.437 \%$ and over 40 were $0.312 \%$.

The marital status of the respondents show $84.687 \%$ were single and $14.375 \%$ were married. As per their educational data $36.562 \%$ were bachelors in business studies, $52.187 \%$ were pursuing masters, $8.437 \%$ were MPhil scholars and $2.812 \%$ were Ph.D. scholars. Employment status indicates that only $15 \%$ of the respondents were working along with their studies while the rest were not working. Furthermore their salaries and pocket money was also recorded for future use. $4.062 \%$ of the respondents were earning below the range of 20,000 PKR, $3.125 \%$ of respondents were doing a job and their earning was between the range of 20,000-30,000 PKR, $2.812 \%$ of the respondents were earning between the range of $31,000-40,000 \mathrm{PKR}$ while $5 \%$ of the respondents were earning were more than 40,000 PKR.

Those categories of the respondents who were not earning and were dependent on their families were also included in this research. $85 \%$ of the total respondents were dependent upon their pocket money in which $43.125 \%$ were consuming less than 5000 PKR, $28.437 \%$ were spending between the ranges of 5000-10,000 PKR, 9.687\% respondents were spending between the range of $11,000-15,000$ PKR and the last $3.75 \%$ of the respondents were spending more than 15,000 PKR. Overall $71 \%$ of the total respondent spending falls between the range of $0-10,000$ PKR which also shows the low-income level of the target respondents.

Reliability and validity were measured by reflective measurement of loading on their factors. Table 2 shows the values of each factor loaded on their relevant items. According to Yoo and Alavi (2001) the rule of thumb for retaining the items is that they must have a value equal to or greater than (0.70). According to Wong (2013), the items having factor loading between (0.05 and 0.06) can be retained on the basis of their contribution in average variances extracted in the 
Relationship between eWOM and purchase intention...

\begin{tabular}{|c|c|c|c|c|c|c|}
\hline Variable & $\begin{array}{l}\text { Variable Di- } \\
\text { mensions }\end{array}$ & $\begin{array}{l}\text { Cronbach's } \\
\text { Alpha }\end{array}$ & $\begin{array}{l}\text { Composite } \\
\text { Reliability }\end{array}$ & AVE & Items & $\begin{array}{l}\text { Item } \\
\text { Load- } \\
\text { ings }\end{array}$ \\
\hline \multirow[t]{20}{*}{ eWOM } & $\begin{array}{l}\text { Source Credi- } \\
\text { bility (SC) }\end{array}$ & 0.711 & 0.832 & 0.641 & SC_1 & 0.61 \\
\hline & & & & & SC_2 & 0.56 \\
\hline & & & & & SC_3 & 0.59 \\
\hline & & & & & SC_4 & 0.62 \\
\hline & $\begin{array}{l}\text { Brand Equity } \\
\text { (BE) }\end{array}$ & 0.749 & 0.801 & 0.644 & BE_1 & 0.63 \\
\hline & & & & & BE _2 & 0.68 \\
\hline & & & & & BE _3 & 0.55 \\
\hline & & & & & BE _4 & 0.69 \\
\hline & $\begin{array}{l}\text { Brand Image } \\
(\mathrm{BI})\end{array}$ & 0.605 & 0.816 & 0.564 & BI-1 & 0.55 \\
\hline & & & & & BI -2 & 0.59 \\
\hline & & & & & BI -3 & 0.54 \\
\hline & & & & & BI -4 & 0.58 \\
\hline & $\begin{array}{l}\text { Consumer } \\
\text { Review (CR) }\end{array}$ & 0.669 & 0.802 & 0.591 & $\mathrm{CR} \_1$ & 0.61 \\
\hline & & & & & $\mathrm{CR} \_2$ & 0.6 \\
\hline & & & & & CR _3 & 0.63 \\
\hline & & & & & CR _4 & 0.63 \\
\hline & & & & & CR _5 & 0.61 \\
\hline & & & & & CR _6 & 0.63 \\
\hline & & & & & $\mathrm{CR}_{-7} 7$ & 0.65 \\
\hline & & & & & $\mathrm{CR} \_8$ & 0.63 \\
\hline \multirow[t]{9}{*}{$\begin{array}{l}\text { Organization Cul- } \\
\text { ture }\end{array}$} & $\begin{array}{l}\text { Organization } \\
\text { Culture }\end{array}$ & 0.719 & 0.882 & 0.641 & CUL_1 & 0.59 \\
\hline & & & & & CUL _2 & 0.69 \\
\hline & & & & & CUL _3 & 0.66 \\
\hline & & & & & CUL _4 & 0.63 \\
\hline & & & & & CUL _5 & 0.55 \\
\hline & & & & & CUL _6 & 0.54 \\
\hline & & & & & CUL _7 & 0.58 \\
\hline & & & & & CUL_8 & 0.54 \\
\hline & & & & & CUL _9 & 0.62 \\
\hline \multirow[t]{4}{*}{ Purchase Intention } & $\begin{array}{l}\text { Purchase In- } \\
\text { tentions }\end{array}$ & 0.799 & 0.855 & 0.688 & PIT_1 & 0.73 \\
\hline & & & & & PIT _2 & 0.76 \\
\hline & & & & & PIT _3 & 0.68 \\
\hline & & & & & PIT_4 & 0.75 \\
\hline
\end{tabular}

model. But items with factor loading (0.40) must be restrained from the model as it creates problems during structural modeling (Hult et al 2018).

In the current model factor loading of various items is between (0.5 and $0.76)$. Table 2 also depicts information about composite reliability and average variances extracted (AVE) values of different factors of the construct. Values of composite reliability for Source Credibility is 0.832; Brand Equity is 0.801; Brand Image is 0.816 and Consumer review is 0.802 . For moderating variable culture composite reliability is $(0.882)$ followed by Purchase Intention having 0.855 . From table 2 , it is clear that the $(\mathrm{CR})$ values are higher than the threshold level of (0.8), while (AVE) values are higher than (0.50) which shows that

Business Review: (2021) 16(1):101-120 
at least $50 \%$ of related variances are explained by their relevant variables of the model (Hult et al 2018). Table 2 also clearly indicates that all the variables AVE values are higher than (0.50), hence the convergent validity assumption is fullfilled.

In order to establish discriminant validity the procedure proposed by Fornell and Larcker (1981) was adopted. According to this assumption, the values of AVE must be higher than the inter-correlation among variables, while Hult et al (2018); Saif et al (2016) stress that the square root value of (AVE) of the variables must be higher than the correlation values of the variable. From table 3 it is clearly evident that inter-correlation among the variables is lower and fulfills the criteria proposed by (Hult et al 2018).

From table 3 it is clearly shown that the correlation between Culture and

Table 3: Discriminant validity values

\begin{tabular}{|c|c|c|c|c|c|c|c|}
\hline & 1 & 2 & 3 & 4 & 5 & 6 & 7 \\
\hline 1. Purchase intention & -0.812 & & & & & & \\
\hline 2. Culture & 0.339 & -0.801 & & & & & \\
\hline 3. Brand Image & 0.301 & 0.288 & -0.782 & & & & \\
\hline 4. Brand Equity & 0.219 & 0.133 & 0.217 & -0.708 & & & \\
\hline 5. Source Credibility & 0.569 & 0.293 & 0.180 & 0.354 & -0.755 & & \\
\hline 6. Consumer Review & 0.710 & 0.333 & 0.298 & 0.412 & 0.539 & -0.795 & \\
\hline 7. eWOM & 0.519 & 0.329 & 0.357 & 0.443 & 0.427 & 0.692 & -0.822 \\
\hline
\end{tabular}

PI is (0.339) which is less than the AVE value in table 2. The correlation coefficient between the credibility of the message source and the purchase intention is $(\mathrm{r}=0.569)$. The relationship of brand equity on customer purchase intention is $(\mathrm{r}=0.219)$, while the relationship between consumer reviews and the customer purchase intention is $(\mathrm{r}=0.710)$. The correlation coefficient between brand image and purchase intention is $(\mathrm{r}=0.301)$, followed by eWOM and PI (0.519), eWOM and consumer review (0.692), eWOM and source credibility (0.42). Finally, the relationship between eWOM and brand image is (0.357). All the correlational values are lower than shared average variances extracted values.

\subsection{Regression analysis}

Regression analysis is used for testing the hypotheses to determine whether they are accepted or rejected. The first hypothesis of this study proved the effect of eWOM on purchase intention. In table 4 the value of $R^{2}$ depicts that overall $27 \%$ of the variances in purchase intention of the customers are explained by the model, while from the coefficient table, the beta value shows that there is a positive and significant relationship between eWOM and purchase intention. The empirical result shows that a unit change in eWOM will bring on average 0.85 units change in purchase intention. The results of the current study are in line with the findings of (Fan and Miao 2012; Jalilvand and Samiei 2012; Sharifpour et al 2016; Malik et al 2016). The current study also indicates eWOM as a strong factor to influence customer purchase intention and will play a sup- 
portive role in firms that are involved in online businesses.

The first hypothesis has four further sub hypothesis which are discussed below: H1a: There is a significant relationship between source credibility and purchase intention

The estimated results in table 9 exhibit a positive and significant effect

Table 4: Model Summary

\begin{tabular}{lcccc}
\hline Model & $\mathrm{R}$ & $R^{2}$ & $\operatorname{Adj} R^{2}$ & Std. Error \\
\hline 1 & 0.519 & 0.270 & 0.267 & 0.75009 \\
\hline
\end{tabular}

Table 5: ANOVA

\begin{tabular}{llccccc}
\hline Model & & $\begin{array}{l}\text { Sum of } \\
\text { Squares }\end{array}$ & Diff & $\begin{array}{l}\text { Mean } \\
\text { Square }\end{array}$ & F & Sig \\
\hline \multirow{2}{*}{1} & Regression & 66.033 & 1 & 66.033 & 117.365 & 0.000 \\
& Residual & 178.917 & 318 & 0.563 & & \\
& Total & 244.95 & 319 & & & \\
\hline
\end{tabular}

Table 6: Coefficients

\begin{tabular}{ccccccc}
\hline Model & & \multicolumn{2}{l}{$\begin{array}{l}\text { Unstandardized } \\
\text { Coefficients }\end{array}$} & $\begin{array}{l}\text { Standardized } \\
\text { Coefficients }\end{array}$ & t value & Sig. \\
\hline \multicolumn{1}{c}{ B } & Std. Error & Beta & & \\
\hline 1 & (Constant) & 0.442 & 0.194 & & 2.277 & 0.023 \\
& EWOM & 0.853 & 0.079 & 0.519 & 10.834 & 0 \\
\hline
\end{tabular}

Table 7: Model summary

\begin{tabular}{lcccc}
\hline Model & $\mathrm{R}$ & $R^{2}$ & Adj $R^{2}$ & Std. Error \\
\hline 1 & 0.772 & 0.597 & 0.592 & 0.560 \\
\hline
\end{tabular}

Table 8: ANOVA

\begin{tabular}{llccccc}
\hline Model & & Sum of Squares & Diff & Mean Square & F & Sig. \\
\hline \multirow{2}{*}{1} & Regression & 146.164 & 4 & 36.541 & 116.519 & 0.000 \\
& Residual & 98.786 & 315 & 0.314 & & \\
& Total & 244.950 & 319 & & & \\
\hline
\end{tabular}

on purchase intention of source credibility and thus supports H1 that message source credibility has a significant impact on consumer purchase intention where

Business Review: (2021) 16(1):101-120 
S. Obaidullah et. al

Table 9: Coefficients

\begin{tabular}{|c|c|c|c|c|c|c|}
\hline \multirow[b]{2}{*}{ Model } & & \multicolumn{2}{|c|}{$\begin{array}{l}\text { Unstandardized } \\
\text { cients }\end{array}$} & \multicolumn{3}{|l|}{$\begin{array}{l}\text { Standardized } \\
\text { Coefficients }\end{array}$} \\
\hline & & B & Std. Error & Beta & $\mathrm{T}$ & Sig. \\
\hline \multirow[t]{5}{*}{1} & (Constant & -0.161 & 0.147 & & -1.094 & 0.275 \\
\hline & Brand Image & 0.209 & 0.047 & 0.190 & 4.455 & 0 \\
\hline & Brand Equity & 0.039 & 0.042 & 0.034 & 0.930 & 0.353 \\
\hline & Source Credibility & 0.246 & 0.047 & 0.236 & 5.255 & 0 \\
\hline & Consumer Rev & 0.566 & 0.052 & 0.489 & 10.967 & 0 \\
\hline
\end{tabular}

the consumer relies on the message sender. The coefficient of source credibility depicts that $24 \%$ purchase intention of the customer is created through the credibility of the message source. When the sender is trustworthy it increases the intentions of the consumers to purchase. Hence credibility of the source is declared as an integral part of generating customer purchase intention. Those online stores that have high credibility among the customers will get the maximum flow of customers. As a result, their sales volume will be higher than the least credible online stores.

The next hypothesis, H1b: 'There is a significant relationship between brand equity and purchase intention' is rejected. The result of this study does not comply with the results of Chen and Chang (2008); Buil et al (2013); Ahmed and Zahid (2014); Sharif et al (2016) which show a positive and significant relationship between brand equity and purchase intention. Different factors can be the reason for the rejection of this hypothesis but more obvious is the income level of the target respondents. Statistics of the current study show that $85 \%$ of the respondent do not have their personal source of income which shows that they were dependent on their families. Out of the $85 \%, 43 \%$ marked their pocket money as ranging less than 5000 PKR and the rest of the $28 \%$ as ranging between 5000 to 10000 PKR which ultimately shows the low financial positions of respondents. Brand equity states customer willingness to pay more for a product but with such low financial standard customers of the targeted area cannot afford to pay more for certain products.

The third hypothesis of the study is, H1c: There is a significant relationship between consumer reviews and purchase intention. The empirical results given in table 9 show a positive and statistically significant effect on purchase intention of a consumer review. Thus we cannot reject the proposed hypothesis. The estimated results show that $56 \%$ of consumer reviews play a vital role in making customer purchasing intentions. The results of the current study for Khyber Pakhtunkhwa are in line with the results of Al Mana and Mirza (2013) for KSA, and Constantinides and Holleschovsky (2016) for Netherland.

Our fourth hypothesis for this study is H1d: There is a significant relationship between brand image and purchase intention. There is a positive and statistically significant relationship between brand image and purchase intention of customers as shown in table 9. The estimated coefficient for brand image shows that a $20 \%$ role is played by the brand image to describe the purchase intention of the customers. The same study has been conducted by Esch et al (2006) for Germany and the USA, Diamantopoulos et al (2011) for Australia 
and UK, Jalilvand and Samiei (2012) for Iran, Malik et al (2013) for Pakistan, and Wang and Tsai (2014) for Thailand. The empirical results of these studies show a positive and significant relationship between brand image and purchase intention. The results of our current study for Khyber Pakhtunkhwa support the results of the aforementioned researchers.

5.3 Moderation analysis results

Table 10: Moderation analysis

\begin{tabular}{lcccccc}
\hline & $R^{2}$ & MSE & F & df1 & df2 & P \\
\hline & 0.309 & 0.5354 & 47.127 & 3 & 316 & 0 \\
& Effect & SE & $\mathrm{t}$ & $\mathrm{p}$ & LLCI & ULCI \\
Constant & -1.145 & 0.7877 & -1.4549 & 0.1467 & -2.6936 & 0.4035 \\
Culture & 0.4224 & 0.3529 & 2.3303 & 0.024 & 0.128 & 1.5167 \\
eWOM & 0.2259 & 0.3251 & 3.7702 & 0.0002 & 0.5862 & 1.8656 \\
Int_1 & -0.212 & 0.1412 & -1.5015 & 0.1342 & -0.4898 & 0.0658 \\
\hline
\end{tabular}

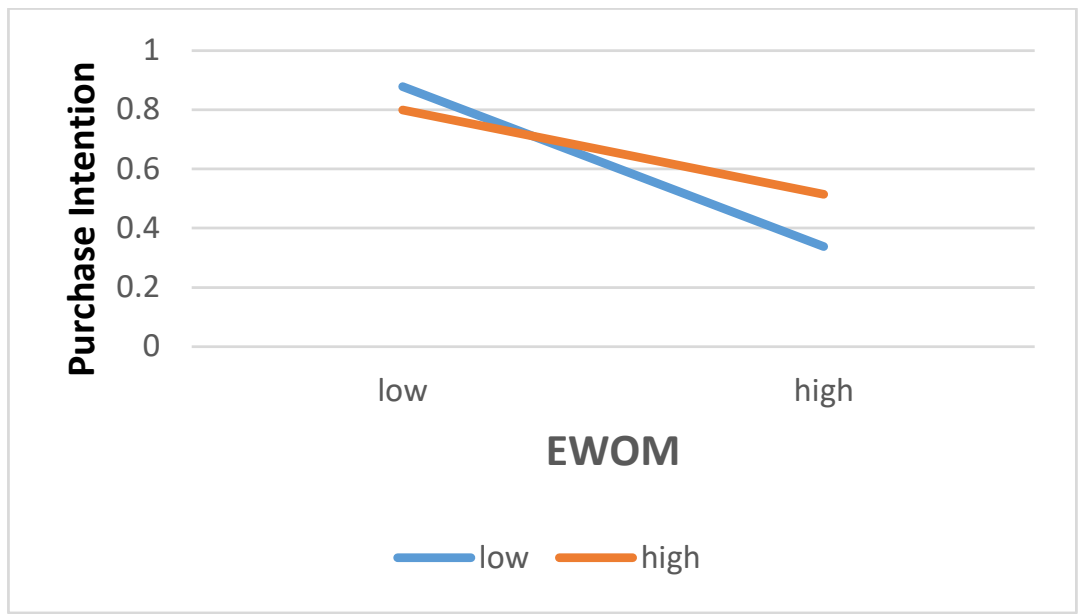

Fig. 3: Impact of eWOM on purchase intention with culture as a moderator

H2: 'There is moderating role of culture on the relationship between eWOM and purchase intention'. In order to check the moderating role of culture, Macro was used to analyze the results. For this purpose bootstrapping at 5000 resample was set and then model one was selected to analyze the moderating role of culture. Table 10 shows the results of the direct effect as well as the interaction effect. From the table, it is clearly shown that the lower level value of confidence interval in model 1 is $(-0.4898)$ and the upper-level confidence interval value is (0.0658).

As ' 0 ' lies between the values ULCI and LLCI, this shows that the culture

Business Review: (2021) 16(1):101-120 
could not act as a moderator. In order to draw the graph for moderation, we also put the values from the table titled (Data for visualizing the conditional effect of $\mathrm{X}$ on $\mathrm{Y}$ ) in MS excel. The cross interaction of the cultural arrow shows an insignificant relationship between eWOM and purchase intention. Therefore it can be concluded that the variable culture does not moderate the relationship between eWOM and customer purchase intention. As the result for moderation is insignificant so hypothesis $\mathrm{H} 2$ is rejected.

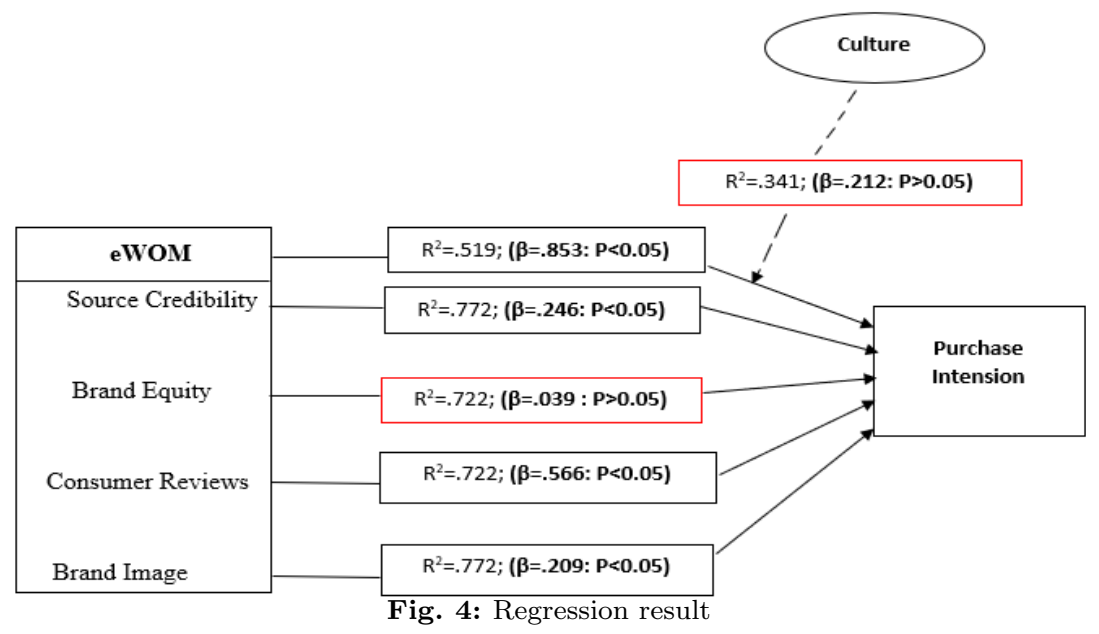

\section{Conclusion}

The trend of using the internet is getting more eminent where different numbers of online users share their views and experiences across the world. In different countries, eWOM is observed as an independent variable in different perspectives. But the current study investigated the impact of eWOM on customers' purchase intention with the moderating role of culture between eWOM and purchase intentions. Detailed and latest literature is reviewed for this purpose to explore the findings of eWOM and customer purchase intention. However, current findings clarify that the free availability of information affects the customer purchasing behavior which ultimately affects those firms involved in online businesses. It is also proved by the current study that eWOM has a significant relationship with customer purchase intentions.

Source credibility, Brand equity, Consumer reviews, and Brand image were the variables used as a medium to measure eWOM, the same is suggested by a different number of researchers as already mentioned in the current theoretical framework of the study. The current study investigates the importance of source credibility and its significant relationship with customer purchase intention. Above mentioned variables are observed as the latest ones to measure eWOM from the current scenario of online businesses. Customer's income level 
plays a vital role in purchase intention because customers with low incomes were not willing to pay more price for product purchasing so the results of the current study reject the hypotheses that brand equity has a significant relationship with customer purchase intention. This results are in contrast with the findings of Ahmed and Zahid (2014); Sharifpour et al (2016).

Results of the current study indicate that today's customer is more conscious about the image of the brand and mostly brand positioning plays an important role in developing customer minds to purchase products/services. Findings further revealed that the brand image of the product has a significant relationship with the customer purchase decision. This finding complies with the results of Jalilvand and Samiei (2012); Malik et al (2013); Wang and Tsai (2014). The current study rather appears to be the first study all over Pakistan where culture is taken as a moderator between eWOM and purchase intention. But the results of the study do not comply with that of Dang and Nandakumar (2017) and showed that culture does not moderate the relationship between eWOM and purchase intentions.

\section{Theoretical contributions}

The current study is based on the theoretical foundation of word of mouth. The study emphasizes that consumer experiences of any product or service become noteworthy if the information and experiences are shared by close friends, peers, or group members. Traditional marketing strategies may also play their contributing role in shaping consumer behavior but psychologically customer first shares information with his/her close circle and then behavior modification is initiated.

The current study moves one step forward as compared to the traditional ways of a relationship to alter one's behavior about any product or service. If a customer wants to purchase anything or his group wants to purchase anything and either of them has no information about a particular product or service then they can take help from the consumer reviews of the product available on the social networking websites. However, shortcomings like the authenticity of online customer reviews, fake IDs, and duplicate contacts raise questions over the authenticity of the eWOM concept. Hence it becomes a researchable topic for future researchers to investigate the authenticity of online consumer reviews to make a solid foundation for the support of the eWOM concept. In the current study, the concept of eWOM is based on specific attributes derived from previous studies to correlate its relationship with purchase intention through culture. As culture results depict no moderation between eWOM and purchase intention, hence the findings contribute toward laying the foundation for a universal cultural approach to seed online behaviors of university graduates.

\section{Future research direction}

In this research the sample was confined only to the Department of Management Sciences of three public sector universities (University of Science and Technol- 
ogy Bannu, Gomal University D.I. Khan, and the University of Peshawar). Data was collected only from three districts Bannu, D.I.Khan and Peshawar due to time constraints For future studies data collection and sample size can be expanded to the other public and private universities across Pakistan. Sample selection could be varied according to the nature of research findings and convenience. eWOM effects on individual dimensions of culture like Long-term versus short-term avoidance, masculinity-femininity, uncertainty avoidance, power distance, and individualism-collectivism needs further exploration. So for moderation analysis single dimension related to culture can be investigated as a moderator between eWOM and purchase intention of the customer which will ultimately change the findings. Furthermore, the current study considers only four dimensions of eWOM while ignores other dimensions like product review ratings, Product Involvement, eWOM Quality, and eWOM Quantity, etc. The influence of the eWOM is checked on the customer purchase intentions. For further studies dependent variable could be replaced with other variables like customer trust, customer equity, and brand preference. and the current model may be applied to other online consumer products like electronic gadgets, etc.

\section{References}

Aaker DA (1991) Capitalizing on the value of a brand name. New York 28(1):35-37

Ahmed MA, Zahid Z (2014) Role of social media marketing to enhance crm and brand equity in terms of purchase intention. Asian Journal of management research 4(3):533-549

Al Mana AM, Mirza AA (2013) The impact of electronic word of mouth on consumers' purchasing decisions. International Journal of Computer Applications 82(9)

Awad NF, Ragowsky A (2008) Establishing trust in electronic commerce through online word of mouth: An examination across genders. Journal of management information systems 24(4):101-121

Babac R (2011) Impact of social-media use on brand equity of magazine brands: A qualitative study of vogue turkey

Bambauer-Sachse S, Mangold S (2011) Brand equity dilution through negative online wordof-mouth communication. Journal of retailing and consumer services 18(1):38-45

Buil I, Martínez E, De Chernatony L (2013) The influence of brand equity on consumer responses. Journal of consumer marketing

Burton J, Khammash M (2010) Why do people read reviews posted on consumer-opinion portals? Journal of Marketing Management 26(3-4):230-255

Calvo-Porral C, Lévy-Mangin JP (2014) Private label brands: major perspective of two customer-based brand equity models. The International Review of Retail, Distribution and Consumer Research 24(4):431-452

Chang CC, Chin YC (2010) The impact of recommendation sources on online purchase intentions: The moderating effects of gender and perceived risk. World Academy of Science, Engineering and Technology 66:111-114

Chen CF, Chang YY (2008) Airline brand equity, brand preference, and purchase intentionsthe moderating effects of switching costs. Journal of Air Transport Management 14(1):40-42

Cheung CM, Thadani DR (2012) The impact of electronic word-of-mouth communication: A literature analysis and integrative model. Decision support systems 54(1):461-470

Cheung MY, Luo C, Sia CL, Chen H (2009) Credibility of electronic word-of-mouth: Informational and normative determinants of on-line consumer recommendations. International journal of electronic commerce 13(4):9-38

Constantinides E, Holleschovsky NI (2016) Impact of online product reviews on purchasing decisions. In: International Conference on Web Information Systems and Technologies, SCITEPRESS, vol 2, pp 271-278 
Dang A, Nandakumar GS (2017) Cultural values and their impact on electronic word-ofmouth (ewom) behavior. In: Marketing at the Confluence between Entertainment and Analytics, Springer, pp 1281-1282

Danniswara R, Sandhyaduhita P, Munajat Q (2020) The impact of ewom referral, celebrity endorsement, and information quality on purchase decision: A case of instagram. In: Global Branding: Breakthroughs in Research and Practice, IGI Global, pp 882-905

Daugherty T, Hoffman E (2014) ewom and the importance of capturing consumer attention within social media. Journal of Marketing Communications 20(1-2):82-102

Davis DE, Worthington Jr EL, Hook JN, Van Tongeren DR (2009) The dedication to the sacred (ds) scale: Adapting a marriage measure to study relational spirituality. Journal of Psychology and Theology 37(4):265-275

Diamantopoulos A, Schlegelmilch B, Palihawadana D (2011) The relationship between country-of-origin image and brand image as drivers of purchase intentions: A test of alternative perspectives. International Marketing Review

Erkan I, Evans C (2016) The influence of ewom in social media on consumers purchase intentions: An extended approach to information adoption. Computers in human behavior 61:47-55

Esch FR, Langner T, Schmitt BH, Geus P (2006) Are brands forever? how brand knowledge and relationships affect current and future purchases. Journal of product \& brand management

Fan YW, Miao YF (2012) Effect of electronic word-of-mouth on consumer purchase intention: The perspective of gender differences. International Journal of Electronic Business Management 10(3):175

Fornell C, Larcker DF (1981) Structural equation models with unobservable variables and measurement error: Algebra and statistics

Gilly MC, Graham JL, Wolfinbarger MF, Yale LJ (1998) A dyadic study of interpersonal information search. Journal of the academy of marketing science 26(2):83-100

Gunther AC (1992) Biased press or biased public? attitudes toward media coverage of social groups. Public opinion quarterly 56(2):147-167

Harris L, Rae A (2009) Social networks: the future of marketing for small business. Journal of business strategy

Hatch SB, Farber RA (2004) Mutation rates in the complex microsatellite mycl1 and related simple repeats in cultured human cells. Mutation Research/Fundamental and Molecular Mechanisms of Mutagenesis 545(1-2):117-126

Hennig-Thurau T, Gwinner KP, Walsh G, Gremler DD (2004) Electronic word-of-mouth via consumer-opinion platforms: what motivates consumers to articulate themselves on the internet? Journal of interactive marketing 18(1):38-52

Hofstede G (1997) The archimedes effect. working at the interface of cultures: 18 lives in social science. mh bond

Hult GTM, Hair Jr JF, Proksch D, Sarstedt M, Pinkwart A, Ringle CM (2018) Addressing endogeneity in international marketing applications of partial least squares structural equation modeling. Journal of International Marketing 26(3):1-21

Hung KH, Li SY (2007) The influence of ewom on virtual consumer communities: Social capital, consumer learning, and behavioral outcomes. Journal of advertising research 47(4):485-495

Jalilvand MR, Samiei N (2012) The effect of electronic word of mouth on brand image and purchase intention: An empirical study in the automobile industry in iran. Marketing Intelligence \& Planning

Keller KL (2001) Building customer-based brand equity: A blueprint for creating strong brands. Marketing Science Institute Cambridge, MA

Kilby N (2007) Market shift opens door to word of mouth. Marketing Week 30(38):12

Knoll J (2016) Advertising in social media: a review of empirical evidence. International journal of Advertising 35(2):266-300

Kozinets RV, De Valck K, Wojnicki AC, Wilner SJ (2010) Networked narratives: Understanding word-of-mouth marketing in online communities. Journal of marketing 74(2):71-89

Malik F, Asif M, Wali S (2016) Role of social media on consumer preferences. City University Research Journal 6(02):256-268

Malik ME, Ghafoor MM, Iqbal HK, Ali Q, Hunbal H, Noman M, Ahmad B (2013) Impact of brand image and advertisement on consumer buying behavior. World Applied Sciences

Business Review: (2021) 16(1):101-120 
Journal 23(1):117-122

Matute J, Polo-Redondo Y, Utrillas A (2016) The influence of ewom characteristics on online repurchase intention: Mediating roles of trust and perceived usefulness. Online Information Review

Mayer RE (2003) Elements of a science of e-learning. Journal of educational computing research 29(3):297-313

Mo Z, Li YF, Fan P, et al (2015) Effect of online reviews on consumer purchase behavior. Journal of Service Science and Management 8(03):419

Ohanian R (1990) Construction and validation of a scale to measure celebrity endorsers' perceived expertise, trustworthiness, and attractiveness. Journal of advertising 19(3):3952

Park DH, Lee J, Han I (2007) The effect of on-line consumer reviews on consumer purchasing intention: The moderating role of involvement. International journal of electronic commerce 11(4):125-148

Pitta DA, Fowler D (2005) Online consumer communities and their value to new product developers. Journal of Product \& Brand Management

Preacher KJ, Hayes AF (2008) Asymptotic and resampling strategies for assessing and comparing indirect effects in multiple mediator models. Behavior research methods 40(3):879-891

Rhyne LC, Teagarden MB, Van den Panhuyzen W (2002) Technology-based competitive strategies: The relationship of cultural dimensions to new product innovation. The Journal of High Technology Management Research 13(2):249-277

Saif N, Khan IU, Khan MH, Khattak MZ (2016) Relationship between human capital devolpment and organization performance. relationship between human capital devolpment and organization performance.(evidence from pakistan banking system). Science International $28(3)$

Schumann JH, Wangenheim Fv, Stringfellow A, Yang Z, Blazevic V, Praxmarer S, Shainesh G, Komor M, Shannon RM, Jiménez FR (2010) Cross-cultural differences in the effect of received word-of-mouth referral in relational service exchange. Journal of International Marketing 18(3):62-80

Sharif MA, Ahmad W, Ahmad A (2016) Electronic word of mouth: investigating the influence of electronic message source credibility, message appeal and brand equity on consumer purchase intention. City University Research Journal 6(1):151-165

Sharifpour Y, Sukati I, Alikhan MNAB (2016) The influence of electronic word-of-mouth on consumers purchase intentions in iranian telecommunication industry. American Journal of Business, Economics and Management 4(1):1-6

Tang L (2017) Mine your customers or mine your business: The moderating role of culture in online word-of-mouth reviews. Journal of International Marketing 25(2):88-110

Triandis HC (2008) Towards the realistic perception of a culture. Social and Personality Psychology Compass 2(5):1812-1823

Turban E, King D, Lee JK, Liang TP, Turban DC (2015) Overview of electronic commerce. In: Electronic commerce, Springer, pp 3-49

Wang YH, Tsai CF (2014) The relationship between brand image and purchase intention Evidence from award winning mutual funds. The international journal of business and finance research 8(2):27-40

Webster FE, Keller KL (2004) A roadmap for branding in industrial markets. Journal of Brand Management 11(5):388-402

West MD (1994) Validating a scale for the measurement of credibility: A covariance structure modeling approach. Journalism quarterly 71(1):159-168

Wong KKK (2013) Partial least squares structural equation modeling (pls-sem) techniques using smartpls. Marketing Bulletin 24(1):1-32

Yamane T (1967) Statistics: an introductory analysis harper and row. new york, evanston and london and john weather hill. Inc, Tokyo

Yasin NM, Noor MN, Mohamad O (2007) Does image of country-of-origin matter to brand equity? Journal of Product \& brand management

Yoo Y, Alavi M (2001) Media and group cohesion: Relative influences on social presence, task participation, and group consensus. MIS quarterly pp 371-390 